\title{
Working Capital Management and Financial Performance of UK Listed Firms: A Contingency Approach
}

\begin{abstract}
Existing empirical research findings generally suggest that working capital management (WCM) affects and the firms' financial performance. This paper adopts contingency theory framework to investigate how the relationship between WCM and financial performance is affected by the firms' environment, resources and management capability. Our sample consist of an unbalanced panel of 802 firms listed on the London Stock Exchange (LSE) from 2004 to 2014 on which a dynamic panel data analysis was performed using a series of interactive models to estimate the relationship. The findings suggest that the impact of WCM on financial performance changes to reflect number contingency variables such as environmental, resources and management capabilities of the firm. These findings are significant because they demonstrate for the first time how the firms' ability to enhance performance through investment in working capital is influenced by contingent factors such as environmental, resource and management capabilities of the firm. Our results are also important as they show that contingency theory helps to provide an understanding on the conditions under which investment in working capital can be an effective tool in enhancing financial performance and the relevant contingencies.
\end{abstract}

Keywords- Working Capital Management, Financial Performance, Contingency Approach, Interactive Models.

JEL Classification: G30; G32; L25; M40 


\section{Introduction}

Existing literature has made several theoretical and empirical contributions on the relationship between working capital management (WCM) and financial performance (Aktas, Croci, and Petmezas 2015; Baños-Caballero, García-Teruel, and Martínez-Solano 2010; Deloof 2003; de Almeida and Eid 2014). Evidence from these studies supports the traditional belief that WCM affects firm's financial performance, risk and consequently its value (Aktas et al., 2015). Despite the strengths of these theoretical and empirical arguments, a number of empirical studies indicate that firms policies change over time as they adjust to the demands of their environment (Rueda-Manzanares, Aragón-Correa and Sharma, 2008; Ambrosini, Bowman and Collier, 2009; Otley, 2016), their resource (Mol and Wijnberg, 2011) and management capabilities (Luo, Kanuri and Andrews, 2014) with the view influencing their financial performance. For example, according to the structure-conduct-performance (SCP) model, the degree of concentration in the industry determines firm behaviour and performance. This is because higher concentration enables collusion between firms which leads to higher profits. It has also been suggested that industrial characteristics such as industry concentration often results in barriers to entry for new firms and enable established firms to share industry profits among themselves (Porter, 1980).

This study extends existing studies by investigating how the impact of WCM on financial performance is likely to change to reflect a number of contingent factors such as environment, resources and management capability of the firm as postulated by contingency theory. This extension is essential for three reasons. First, recent studies (Bastos and Pindado, 2013; Enqvist, Graham and Nikkinen, 2014) have shown that firms cash and liquidity management change to reflect external environmental conditions. According to Otley (2016), firms tend to adopt more formal control and traditional management control systems to enhance their performance during a period of adverse external environmental conditions than favorable conditions. According to Kestens et al. (2012), during a period economic meltdown, firms that use suppliers credit are in better position to keep their operational activities stable and are less likely to experience liquidity constraints. On the other hand, firms that reach a helping hand to their customers by increasing trade credit offered are more likely to achieve additional sales (Nadiri, 1969; Baños-Caballero, García-Teruel 
and Martínez-Solano, 2010). Building on prior evidence, we determine how external environment impacts on working capital performance relationship. Specifically, positive increase in investment in working capital is likely to act as insurance during times of economic downturns. Therefore, firms are less likely to be affected by the adverse effect of holding a substantial level of working capital investment during economic downturns relative to economic booms.

Second, evidence from the resource-based view theory of the firm, suggests that resource heterogeneity produces performance differentials among competing firms (Peteraf, 1993; Hoopes and Madsen, 2008). Several studies have highlighted that working capital investment varies depending on the size of firms due to their resource heterogeneity (Peel, Wilson and Howorth, 2000; Howorth and Westhead, 2003). Peel et al. (2000) assert that smaller firms invest in working capital than large firms. This can be explained by the fact that large firms have regular working capital management routines and they show a higher prevalence of ad hoc or subjective working capital decision-making (Nayak and Greenfield, 1994; Khoury, Smith, and MacKay 1999). Against this backdrop, we can expect that the positive (negative) impact of holding a low (high) level of working capital investment on firm value is more (less) pronounced among smaller firms relative to large firms.

Third, it has also been suggested that a firm's financial performance depends on its conduct in matters such as its management policy (Spanos, Zaralis and Lioukas, 2004). One of such management policies discussed over the years has been on the firms' corporate governance polices (Nicholson and Kiel, 2004; Forbes and Milliken, 2008; Zona, Zattoni and Minichilli, 2013). Several studies have argued that strong corporate governance is necessary to create and maintain sound working capital management policies for the firm to enhance the value of shareholders (Drobetz and Grüninger, 2007; Gill and Biger, 2013). Strong corporate governance is a system by which companies are directed and controlled that facilitates an effective, entrepreneurial and prudent management that can deliver the long-term success of a company. For instance, Gill and Biger, (2013) show that strong corporate governance plays an important role in improving the efficiency of working capital management. According to the authors, firms with strong corporate governance structures can efficiently manage of working capital better. Therefore, strong corporate governance, we argue, is necessary to create and maintain sound working capital management policies to enhance firms' financial performance. 
To test these distinct channels of influence, we adopt a dynamic panel data analysis using general methods of moments (GMM) on a sample of an unbalanced panel of 802 firms listed on the LSE from 2004 to 2014. Evidence of our study offers support to these relational pathways for the effects of WCM on firm financial performance. We find that the impact of working capital management on financial performance changes to reflect number contingency variables such as environmental, resource and management capabilities of the firm.

Our main contribution is by demonstrating, for the first time, how the impact of WCM on firms' financial performance changes under different conditions. While prior studies have provided extensive empirical evidence on the impact of WCM on firms' financial performance, there is still no evidence to demonstrate how the firms' ability to enhance performance through investment in working capital is influenced by contingent factors such as environmental, resource and management capabilities of the firm. We argue that WCM - performance relationship needs to be understood in the context these firm-specific characteristics. That is, the contingency framework helps to provide an understanding on the conditions under which investment in working capital can be an effective tool in enhancing firms' financial performance and which contingencies enhance or constrain firms' ability to achieve this objective.

We also contribute to the limited research evidence on the direct relationship between WCM and financial performance in the UK where current knowledge and understanding is limited given that late payment problems have been identified as a source of business failure. The few existing studies that exist (e.g., Howorth and Westhead 2003; Tauringana and Afrifa 2013) are based on a sample of small firms. Our results based on large listed firms may be different to those based on small firms given that Wilson (2008) suggests that large firms tend to use their market power to exploit their 'dominant' positions as buyers in competitive supply markets by taking 'extended' trade credit and thus leveraging their profit and cash-flow.

The rest of this study is structured as follows: Section 2 is the literature review including hypotheses development. In section 3, we discuss the data and describe the empirical method used to analyse the data. Section 4 presents and discusses the empirical results. Section 5 is the summary and conclusion.

\section{Literature Review and Hypotheses development}

\subsection{Theoretical framework}


This study adopts contingency theory to explain why environment, resources and management variables may moderate the relationship between WCM and financial performance. The theory offers a cogent explanation on the interrelationships among organisational sub-systems as well as between the organisational system and its environment (Fridman and Ostman, 1989). The framework is built on the idea that there is no universally appropriate performance management system that applies equally to all organisations in all conditions, but particular features of the system and its effectiveness depend on specific organisational and context factors (Otley, 1980; Ferreira and Otley, 2005; Wadongo and Abdel-Kader, 2014). Therefore, organisations have to adapt their systems and structures to be congruent with the various contingencies or circumstances of their external environment to be effective (Otley, 2016).

Further, contingency theory postulates that the effectiveness of the organisation in coping with the demands of its environment is contingent upon the different elements of its various sub-systems being designed by the requirements of the environment with which they interact (Burrell, 1979). The contingency approach holds that organisations will be more effective when a match is achieved between the organisation's contextual factors or contingencies (environment, resources and management) and its corporate strategy and organisational structure (Luthans and Stewart, 1977). Therefore, an organisation performance depends on the extent to which the policy that it seeks to pursue is aligned with its organisational design. This alignment between strategy and performance is described as "fit" in the strategic management literature (Venkatraman and Prescott, 1990) The fit is interpreted as an interaction effect of organisational structure and context on performance (Van de Ven and Ferry, 1980). When a firm's structural variable fits at a level that is equal to its organisational contingencies, profitability is enhanced and vice versa (Donaldson, 2001). The better the fit, the more efficient the organisation becomes (Drazin and Ven, 2013). To date, research studies results in other areas are consistent with contingency theory (e.g., Forbes and Milliken 1999; Thorgren, Wincent, and Anokhin 2010; Zona, Zattoni, and Minichilli 2013).

\subsection{Environmental Conditions, WCM and Financial Performance}


Environmental Conditions (EC) are conditions that affect the organisation but are beyond the direct or positive control of the organisation's resource managers (Churchman, 1968). They are usually considered as "givens" or independent variables in the contingency framework since they are not subject to the direct control of management. Wadongo and Abdel-Kader (2013) observed that EC (i.e. environmental unpredictability, turbulence and competition) as one of the most significant contingent variable faced by the organisation. According to Chenhall (2007, p. 173), "[t]he more hostile and turbulent the external environment, the greater the reliance on formal controls and emphasis on traditional budgets". Otley (1978) similarly suggests that tight budget control should be used when faced with severe conditions.

Prior studies (Bastos and Pindado 2013; Enqvist, Graham, and Nikkinen, 2014 Kestens et al. 2012) demonstrate that firms' cash and liquidity management change to reflect external environmental conditions. For instance, Enqvist, Graham, and Nikkinen (2014) assert that the impact of the business cycle on the working capital-profitability relationship is more pronounced in economic downturns relative to economic booms. According to Kestens et al. (2012), during a period financial meltdown, firms that use suppliers credit are in better position to keep their operational activities stable and are less likely to experience liquidity constraints. On the other hand, firms that reach a helping hand to their customers by increasing their trade credit offered are more likely to achieve additional sales (Nadiri, 1969; BañosCaballero, García-Teruel and Martínez-Solano, 2010).

Love et al. (2007) finds that financially vulnerable firms adopt an aggressive trade credit policy by reducing their investment in trade credit during periods of crises. The authors attribute this to the fact that during a period of economic meltdown, alternative sources of financing become scarce as stock markets crash and foreign lenders pull out their money. That is, as all the potential sources of funds dry up, there may be nothing left to redistribute in the form working capital. While firms may demand more of suppliers' credit, suppliers may not be willing to grant such request due to contraction of access to external finance. Ramiah et al. (2016), explains that during crises periods, firms focus more on the preservation of cash and reduction of their cash conversion cycles to secure additional funding buffers for their operational activities. Therefore, by adopting an aggressive WCM policy, firms can 
free up all the excess cash tied up in working capital for profitable investment opportunities.

Several studies focus their analyses on differences in working capital management across industries (Ng, Smith and Smith, 1999; Filbeck and Krueger, 2005). According to Porter (1980), the differences in the performance level of companies within an industry also depends on the bargaining power between the supplier and customer. In an industry with few suppliers but many customers, suppliers may enjoy an enhanced financial performance by dictating to customers; such as determining the price of the products and even the terms of credit to be offered. Nonetheless, fast-growing firms or those operating in competitive markets are more likely to adopt a less formalised and conservative WCM policy to enhance their market share. These firms offer additional credit to extend their market share, and in return, they demand more credit from their suppliers to create equilibrium in their cash conversion cycle (Paul and Boden 2008). By investing in working capital, firms can make higher performance through enhanced operational efficiencies and also increase sales. Building on prior evidence, we determine, for the first time, how EC impacts on WCM- financial performance relationship. Specifically, we propose that an increase in the severity of EC positively affect how much investment in working capital firms need to make in order to enhance their financial performance. We, therefore, hypothesise that:

Hypothesis 1: Environmental conditions positively moderate the positive relationship between WCM and financial performance

\subsection{Resource Capability, Working Capital Management and Firms Performance}

Another essential contingent factor discussed over recent years is resource capability position of organisations. Evidence rooted in the resource-based perspective of the firm has uncovered that the development, deployment and utilisation of resources and capabilities of firms is more likely to determine a firm's ability to enhance their performance (Hambrick and D'Aveni, 1992; Headd, 2003). The review indicates that resource heterogeneity produces performance differentials among competing firms (Peteraf, 1993; Hoopes and Madsen, 2008). According to Headd (2003), firms well-endowed with abundant and quality financial resources and human capital are less likely to fail compared to those with fewer resources. 
One important contingent resource variable which has received limited evidence in management accounting literature is size. Chenhall (2007, p. 183) finds that only a few studies explicitly use size as a contingency variable (see, for example, Bruns and Waterhouse 1975; Merchant 1981; Ezzamel 1990). Donaldson (2001) contend that the size of an organisation is positively associated with a higher degree of formalisation. Merchant (1984) argues that as the number of people in any organisation increases, it becomes less practical to use informal methods of communication and control.

Howorth and Westhead (2003), assert that small firms need to control and monitor their working capital mainly. This is because they are associated with a higher proportion of current assets relative to large firms, less liquidity, volatile cash flows, and a reliance on short-term debt (Peel et al. 2000). Evidence suggests that due to resource constraints, relatively few small firms utilise basic working capital management routines and they show a higher prevalence of ad hoc or subjective working capital decision-making (Nayak and Greenfield, 1994).

According to Peel and Wilson (1996), smaller firms adopt formal working capital management routines to reduce the probability of business closure, as well as to enhance business performance since they have very limited resource capability. A firm's working capital management routines require a formalised method of planning and control. In line with this suggestion, we argue that resource constraint firms that adopt formal controls WCM routines such as reducing investment in working capital can free up excess cash for profitable investment therefore preventing the need for expensive external finance (Autukaite and Molay, 2011). The delaying of payments to suppliers as a result of indulging in an aggressive strategy of WCM can also improve firm performance. Accordingly, we hypothesise that:

Hypothesis 2: Resource capability positively moderates the positive relationship between WCM and financial performance

\subsection{Management Capability, WCM and Financial Performance}

Organisational leadership has been one of the generic contingent variables examined over the years. According to Battilana et al. (2010) effective organisational leadership is essential in addressing performance challenges of an organisation. One of such management policies discussed over the years has been on the firms' 
corporate governance policies (see Zonal et al. 2013). Several studies (Dunn, 2004; Combs et al., 2007) suggest that CEOs whose power remains unchecked by outside directors' CEO might be risk averse, less willing to take on new business ventures and are more likely to take self-serving actions that decrease shareholder wealth. According to the power circulation theory, low CEO's power enhances sufficient monitoring by other executives to protect shareholders interest (see Combs et al., 2007). On the other hand, powerful CEOs may have a positive effect on performance due to their ability to control and influence key boards' decisions despite the potential discontentment from other executives (Fama and Jensen, 1983). Adams, Almeida and Ferreira (2005) report a positive association with the CEOs' power and the variance in stock returns, and also Wu et al. (2011) find a positive relationship between the CEOs' power and the variability in the firms' financial performance.

Kyereboah-Coleman (2008) describe that with dual-responsibility, CEOs who double as board chairs can serve the interests of the management team better due to the lack of undue influence of bureaucratic structures. According to Dahya and Travlos (2000) one way to protect the team's position is to hold excessive corporate liquidity, which negatively affects the firms' net working capital and also firms performance (Baños-Caballero, García-Teruel and Martínez-Solano, 2012; Aktas, Croci and Petmezas, 2015). Therefore, strong corporate governance, we argue, is necessary to create and maintain sound working capital management policies to enhance firms' financial performance. According to Gill and Biger (2013) firms with strong corporate governance structures can efficiently manage of working capital better and is likely to enhance firms' financial performance. Accordingly, we hypothesise that:

Hypothesis 3: management capability positively moderates the positive relationship between WCM and financial performance

\section{Data and empirical method description}

\subsection{Data: sample selection, sources, and description}

The population for the study consists of a sample of 802 firms listed on the London Stock Exchange listed firms for the period 2004 to 2014. To arrive at our final sample, we excluded financial firms such as banks and insurance because they have different accounting requirements (e.g. Zalata et.al. 2018; Hill et al., 2010). The 
criteria were necessary to allow for easy comparability with similar studies and also to permit the use of unbalanced panel data, which has the advantage, as argued by Gujarati (2003), of more degrees of freedom and less multicollinearity among variables. By allowing for both entry and exit, the use of an unbalanced panel partially mitigates potential selection and survivor bias. The final sample extracted from three data sources (Thompson one Analytics, Boardex and Fame accounting data stream.), was narrowed down from 1316 listed firms to an unbalanced panel of 802 firms, representing 6,424 firm-year observations.

\subsubsection{Dependent variable}

The study adopts two main dependent variables to measure financial performance: return on assets (ROA) and Tobin's q ratio (QRATIO). Consistent with prior literature (e.g., Tauringana and Afrifa 2013), ROA is measured as the ratio of net income for the year scaled by total assets. It captures how firms' internal utilisation of resources could be translated into internal performance. However, since these firms are listed firms, we adopt QRATIO to determine how effective utilisation of the firm resources could be used to create value to shareholders. Moreover, Afrifa and Tingbani (2018) argues that market based performance measure is best suited for listed firms because it affects investments and financing choices of firms (Kieschnick, Laplante, and Moussawi 2013; Ek and Guerin 2011).

\subsubsection{Independent variables}

The study has two sets of independent variables. The first variable of interest is WCM, which measures the firm's investment in working capital. Consistent with other studies (Aktas et al. 2015; Hill et al. 2012) we define WCM as the Net operating working capital (inventories plus receivables minus accounts payable) scaled by sales. The second set of variables includes the set of contingent variables. These variables moderate the relationship between WCM and firms performance. These contingencies are classified into three components by Luthan and Steward (1977): Environmental, Resources and Management variables of the firm. Environmental variables (E) include factors that affect the organization, but are beyond the direct or positive control of the organization's resource managers Churchman (1968). According to, Chenhall (2007, p. 173), "[t]he more hostile and turbulent the external environment, the greater the reliance on formal controls". 
Following prior studies of Wadongo and Abdel-Kader (2013), we adopt financial market turbulence and competitive intensity as the main measures of environmental condition. Financial market turbulence is proxy by the recent financial crisis, which assumes the value of 1 for the crisis period (2007-2009) and 0 other wise. We measured competitive intensity as the degree of competition in an industry using Herfindahl index. Following (Afrifa and Gyapong, 2017), we defined the HerfindahlHirschman index as the sum of the squares of the sales market shares of all the firms in an industry.

Resource variables $(R)$ include those tangible and intangible factors over which management has more direct control and on which it operates to produce desired changes in the organizational system or its environmental supra-system (Churchman, 1968). Following prior studies in contingency research (Chenhall 2007, Donaldson 2001; Otley 2016); we adopt size, which is measured by the total number of employees, as a proxy for the firm's resource variable.

Management variables (M) include those concepts and techniques expressed in policies, practices and procedures used by the manager to operate on available resource variables in defining and accomplishing system objectives (Luthans and Stewart, 1977). In order to measure management capability, we construct a measure for CEO ability. Following Mollah and Liljeblom (2016), we construct an index based on six dummy variables (i.e. it is a sum of six binary variables). The variables measure (a) if there is a CEO-Chair duality, (b) if the CEO is internally recruited, (c) if the age of the CEO is greater than median age, (d) if the CEO's tenure is greater than median tenure, (e) if the CEO's banking experience is greater than the median banking experience, and ( $f$ ) if the CEO's qualifications surpass the median qualifications. If a condition exists, the dummy equals one, and zero otherwise.

\section{[Insert Table 1 about here]}

\subsubsection{Control Variables}

We include other variables to control for other changes in financial characteristics. These control variables include: financial leverage (FLEV), which is defined as the total debt as a percentage of total assets (Aktas et al., 2015); firm age (AGE), which is defined as the number of years between incorporation and the calendar year end of each firm (Afrifa and Tingbani, 2018); tangible fixed assets 
(TAN), which is defined as the fixed assets as a percentage of total assets (Afrifa et. al., 2015); sales growth (GROWTH), which is defined as the annual sales growth (Sales - Salest-1)/Salest-1 (Baños-Caballero, et al., 2014) and Current ratio (CR), measured as current assets divided by current liabilities at the end of the financial year (Tauringana and Afrifa, 2013).

\subsection{Regression Model and Specification}

\subsubsection{Econometric estimation}

The following dynamic panel models using the generalized method of moments (GMM) approach (Arellano and Bond, 1991) are used to estimate the relationship between working capital, its contingencies and financial performance. The estimation approach used is Arellano and Bover (1995) and Blundell and Bond (1998) 'system GMM'. The system GMM estimator has the advantage of controlling for endogeneity of the individual explanatory variables, control for the nonobservable constant heterogeneity arising out of the specific features of each firm that remain over time and above all improve the efficiency of econometric estimates as it allows the introduction of more instruments.

We control for firm-specific, time-invariant effects, and for the possible endogeneity of the regressors, by using a first-difference GMM approach. Lags of each of the regressors (including the interaction terms) are used as instruments. Both time dummies and industry dummies interacted with time dummies and included in all our regressions. The validity of GMM estimates depends on the absence of second-order serial autocorrelation in the residuals and on the validity of the instruments analysed: note that first-order serial correlations are significant by way of construction. For this reason, we report both the first- (AR1) and the secondorder (AR2) test for serial correlation, which are asymptotically distributed as a standard normal under the null of no serial correlation of the differenced residuals. In addition, we also report the Hansen test for over-identifying restrictions that confirms the validity of the selected instruments. All these conditions were met in all our estimations.

$$
\begin{aligned}
& \gamma_{i, t}=\beta_{0}+\beta_{1} \gamma_{i, t-1}+\beta_{2} X_{i, t}+\beta_{3} Z_{i, t}+\lambda_{t}+V_{i}+\varepsilon_{i, t} \\
& \gamma_{i, t}=\beta_{0}+\beta_{1} \gamma_{i, t-1}+\beta_{2} X_{i, t}+\beta_{3} Z_{i, t}+\beta_{4} K_{i, t}+\lambda_{t}+V_{i}+\varepsilon_{i, t}
\end{aligned}
$$


$\gamma_{i, t}$ is firm performance measured by: ROA and QRATIO; Xi,t is a matrix of the main independent variable of interest working capital management (WCMi,t). $Z$ is a vector representing the control variables (financial leverage (FLEVi,t), firm age (AGEi,t), tangible fixed assets (TANi,t), and sales growth (GROWTHi,t)). $K$ represents the interactive term between working capital management and Environmental variables (WCM $\times$ E); working capital management and Resource variable (WCM $\times \mathrm{R}$ ); working capital management and Management variables (WCM $\times M$ ). The $V_{i}$ is the unobserved firm effects (fixed effects), the parameter $\lambda_{t}$ is the time dummy variable; $\varepsilon_{i t}$ the idiosyncratic shocks. $\boldsymbol{\beta}_{1}$ and $\boldsymbol{\beta}_{2}$ are vectors of parameters to be estimated.

\section{[Insert Table 2 about here]}

\subsubsection{Descriptive Statistics}

Descriptive statistics of the independent and dependent variables are presented in Table 2. From the table, firms make an annual average return on assets and QRATIO of 5 per cent and 1.492 respectively.

The average mean and median of CCC is 65.901 days and 72.446 days respectively, which suggests that on average most listed firms are slow in converting their inventory into sales and paying their suppliers but fast in receiving payments from their customers. The evidence confirms Wilson's (2008) findings of late payment problem among UK firms with large firms being the worse culprits due to their long bureaucratic procedures for processing invoices. According to Wilson (2008), larger firms take an average of over 74 days to settle their invoices whiles small and medium firms take over 58 day. The average GROWTH is 12.696 per cent with a median of 12.479 per cent. FLEV has a mean 11.398 per cent and median of 5.710 per cent. The mean and median $C R$ is 1.590 and 1.280 respectively. For ATAN, the mean is 37.179 per cent with a median of 26.204 per cent. Finally, the results show an average age and a mean of mean of 19.842 years and 15.71 years respectively.

Table 3 presents the correlation matrix for all the continuous variables included to test the association between WCM and firms' financial performance. The evidence presented in the table indicates significant correlations among the various continuous variables. The variables (ROA and QRATIO) show a significantly negative correlation with WCM. Variables ROA and QRATIO show significantly 
positive correlations with AGE, CR and GROWTH, while negatively correlated with, ATAN and FLEV.

\section{[Insert Table 3 about here]}

\section{Empirical Results}

\subsection{The baseline specification and method}

Table 4 presents the baseline estimation on the relationship between WCM and financial performance of the firms in our panel and their characteristics. Column 1 and 2 in Table 4 ignore the influence of the controls, while the remaining columns (3 and 4) include the control variables. Consistent with our expectations, both columns confirm a significant negative relationship between firms' financial performance (ROA and QRATIO) and WCM. The relationship is significant at 1 per cent in all the columns.

The relationship between WCM and financial performance is also significant once the control variables have been included in Columns 3 and 4 in Table 4 . Our evidence suggests that reducing investment in WCM can help boost the performance of firms. High level of WMC often generates higher opportunity and financing costs (Kieschnick et al., 2013) which could seriously constrain the firms' ability to pursue an optimal investment policy so as to enhance their financial performance. Therefore, by reducing investment in WCM, firms are able to free the excess cash tied up in working capital for value enhancing investment projects in the short run (Aktas et al. 2015). These results support the findings by prior studies (Aktas et al., 2015; Garcia-Teruel and Martinez-Solano, 2007 and Autukaite and Molay, 2011) that reducing the requirement in working capital leads to less need for external financing and less cost of capital, which increases performance.

Regarding the control variables, the study finds the coefficient estimates of AGE, FLEV, ATAN and GROWTH to be statistically significant at conventional level. In particular, we find performance to decrease with AGE, ATAN and FLEV. This is consistent prior studies (Aktas et al 2015; Afrifa and Tingbani 2018). Consistent with Afrifa and Tingbani (2017), we also found GROWTH to be significant and positive association with performance, indicating that higher sales improve firm performance.

\section{[Insert Table 4 about here]}




\subsection{Environmental Conditions, Working Capital Management and Financial}

Performance

As proposed in model 2, there are interactions that influence the scale of the impact of WCM on firms' financial performance. The most important of these discussed in the literature are environmental conditions such as competition and financial market turbulence. The central hypothesis is that firms are more likely to adopt more formal controls such as reducing investment in working capital to enhance their performance when faced with severe EC.

Table 5 and 6 present empirical evidence on the relationship between WCM, $E C$ and firms' financial performance. Evidence from both regressions (columns 1 and 3 , Tables 5 and 6 ) show significantly positive relation between competitive intensity and firms' financial performance (ROA and QRATIO). The findings suggest that competition intensity has a significantly positive influence on firms' financial performance. This is consistent with Nickell (1999). We also find a significantly negative relationship between financial crisis and firm performance, which suggests that financial market turbulence adversely affect the performance of firms. The overall evidence from measures of EC suggests that EC significantly impacts on the performance of firms.

However, when we interact the EC variables with WCM in Table 6, we find the interactive terms (WCM $\times$ COMPETITION and WCM $\times$ CRISIS) becomes significantly positive confirming $\mathrm{H} 1$ that EC positively moderates the relationship between WCM and firms' financial performance. In particular, the evidence suggests that relationship between WCM and firm performance is influenced by EC (COMPETITION and CRISIS) such as the degree of competition in the industry and financial market turbulence. According to our evidence, firm operating within very competitive industries are able to perform more (less) if they increase (decrease), their investment in WCM compared to operating in less competitive industries. We attribute this to the fact that firm operating within very competitive industries need to offer very generous credit to their customers as a competitive tool in enhancing sales and market share (e.g., Hill et al. 2012). On the other hand, during periods of financial market turbulence (eg. financial crisis), firms focus more on the preservation of cash and reduction of their cash conversion cycles to secure additional funding 
buffers for their operational activities. Therefore, by adopting an aggressive WCM policy, firms can free up all the excess cash tied up in working capital for profitable investment opportunities. The coefficient estimates of WCM, AGE, FLEV, ATAN and GROWTH are still statistically significant at conventional level as previously determined in Table 4.

\section{[Insert Table 5 and 6 about here]}

\subsection{Resource Capability, Working Capital Management and Financial Performance}

We further explore this analysis by looking at the potential impact of resource capability on the relations between WCM and firms' financial performance. We investigate whether WCM may vary based on the resource constraint of firms. Our argument is built on the premise that, owing to the scarcity of access to financial resources, resource constrained firms are more likely to observe high performance when they adopt formal controls WCM routines than less constrained firms. Table 7 presents evidence of the relationship between WCM, R and firm performance.

Evidence from Table 7 (columns 1 and 2) show significantly positive relation between R (SIZE) and firms' financial performance (ROA and QRATIO). The findings suggest that $R$ has a significantly positive influence on firm performance. This is consistent prior studies (e.g., Otley, 2016; Wadongo and Abdel-Kader, 2013) that link size of the firms' resource capacity to perform. In line with these studies, our study contends that due to their resource capability, large firms perform better than small firms.

Columns 3 and 4 of Table 7, show the results of the interaction between WCM and $R$ on firm performance. We find the coefficient of the interactive term (WCM $X R)$ becomes significantly positive confirming $\mathrm{H} 2$ that $\mathrm{R}$ (SIZE) positively moderates the relationship between WCM and firm performance. Specifically, the findings suggest firms' with less resource capacity especially smaller firms, adopt formal controls in their WCM routines to enhance their performance than less constrained firms (large firms). The evidence supports current contingency studies (Donaldson 2001; Howorth and Westhead 2003; Otley 2016) linking size to formalisation. We argue that since smaller firms have higher proportion of current assets (working capital) relative to large firms, it will be beneficial for them to adopt formal control in their 
WCM routines to enhance their performance. By adopting formal controls, smaller firms will be able to control, monitor and eliminate any unnecessary cash tied up in their working capital in order to enhance their performance. Consistent with previous Tables (4, 5 and 6), the study finds the coefficient estimates of WCM, AGE, FLEV, ATAN and GROWTH to be statistically significant at conventional level.

\section{[Insert Table 7 about here]}

\subsection{Management Capability, Working Capital Management and Financial} Performance

In this section we present results on the relationship between WCM, management capability and firms' financial performance. Results of this relationship are presented in Table 8. Here, we argue that strong management framework, is necessary to create and maintain sound working capital management policies to enhance firms' financial performance. The finding from Table 8 (columns 1 and 2) show significantly positive relation between management capability (CEO ENTRENCHMENT) and firms' financial performance (ROA and QRATIO). Our evidence supports Fama and Jensen' (1983) argument that entrenched CEOs have positive influence on the financial performance of their firms due to their ability to control and influence key boards' decisions despite the potential discontentment from other executives. This is consistent with empirical work by Adams et al. (2005) and Wu et al. (2011).

However, when we interact the management variable (CEO ENTRENCHEMENT) with WCM in Table 8, we find the coefficient estimates of the interactive term (WCM $\times$ CEO ENTRENCHEMENT) to be significantly positive confirming $\mathrm{H} 3$ that $\mathrm{M}$ positively moderates the relationship between WCM and firm financial performance. The evidence supports Gill and Biger's (2013) argument that firms with strong corporate governance structures can efficiently manage their working capital which we argue is likely to enhance firms' financial performance. Specifically, firms with entrenched (less entrenched) CEOs increase (decrease) their investment in working capital to enhance firms' financial performance. This can be explained by the fact that entrenched CEOs, CEOs whose power remains unchecked by outside directors CEO are often less willing to take on new business ventures, more likely to be risk averse and often take self-serving actions that 
decrease shareholder wealth as suggested by prior studies (Combs et al. 2005; Dunn, 2004). In line with the evidence, firms with entrenched CEOs, by virtue of their risk profile (risk averse), are more likely to be associated with a conservative working capital policy (high investment in working capital), while low entrenched CEOs pursue a more aggressive working capital policy (low investment in working capital) to enhance firms' financial performance.

\section{[Insert Table 8 about here]}

The coefficient estimates for the rest of the variables WCM, AGE, FLEV, ATAN and GROWTH are all statistically significant at conventional level as previously determined.

\section{Additional Analysis and robustness checks}

\subsection{Robustness checks}

We run a series of checks to enhance robustness of our analysis. Our first check was to determine whether our analysis may be sensitive to the type of structure imposed on the model (a dynamic model for the primary results). To assess the implication of the imposed structure of the model on the results, we relax the dynamic nature of the model by estimating the relation using a static model. In the literature both the corrected least squares dummy variable (LSDVC) and the GMM estimators were deigned purposely to handle dynamic panels to correct for Nickel bias, especially in panels with short time periods, where the bias is severe. In panels with period above 30 years, the bias created by the correlation between the lagged dependent variable and fixed effects is small (Judson and Owen, 1999). In such instances, the FE estimator performs well relative to both the GMM and LSDVC. In this study, we opted for the LSDVC to correct for the bias created by the lagged depended on variable in the dynamic model estimation.

Due to the possibility of potential endogeneity problem as a result of possible reverse causation between WCM and firms' financial performance, we use a second-reduced form equation for WCM as specified in eqn. (5), where the residuals for this equation is generated and added into eqn. ( $3 \& 4)$. This is a standard approach to deal with issues of endogeneity when there are no suitable available instruments. We assumed that WCM, contingent factors (environment, resource and 
management) and other firm characteristics are vital factors that influence the level of financial performance of firms and therefore specify the reduced-form model.

$$
\begin{aligned}
& \gamma_{i, t}=\beta_{0}+\beta_{1} X_{i, t}+\beta_{2} Z_{i, t}+\lambda_{t}+V_{i}+\varepsilon_{i, t} \\
& \gamma_{i, t}=\beta_{0}+\beta_{1} X_{i, t}+\beta_{2} Z_{i, t}+\beta_{3} K_{i, t}+\lambda_{t}+V_{i}+\varepsilon_{i, t} \\
& X_{i, t}=\beta_{0}+\beta_{1} \gamma_{i, t}+\beta_{2} Z_{i, t}+\lambda_{t}+V_{i}+\varepsilon_{i, t}
\end{aligned}
$$

Where all the variables are the same as defined for eqn. (2 \&3).

The results based on a fixed effect model are reported in Table 9. The findings from Table 9, suggest a qualitatively similar results as reported in our primary results reported previously using the dynamic model. Our general conclusion based on this sensitivity analysis is that the results are robust to the model structure (static or dynamic) for both the WCM and firms' financial performance models.

In the second sensitivity analysis, test whether our analysis is sensitive to alternative measure of working capital. We adopted the cash conversion cycle (CCC), which measures the average number of days it takes a firm to recoup the amount invested in current assets (Deloof 2003; Afrifa and Tingbani, 2018). The results reported in Table 10 are in line with our previous evidence of the relation between WCM and financial performance.

\section{[Insert Table 9 and 10 about here]}

\section{Conclusion}

The paper presents empirical evidence on the relationship between WCM and financial performance using three contingent variables (environment, resource and management). Using a sample of 802 listed firms from the LSE for the period 20042014, the study finds support for the hypotheses that the impact of WCM on financial performance changes to reflect number contingency variables such as environmental, resource and management capabilities of the firm. Our evidence also supports Gill and Biger, (2013) argument that firms with strong corporate governance structures can efficiently manage their working capital better, which we find to enhance firms'. Specifically, we find that firms with powerful (Less powerful) 
CEOs increase (decrease) their investment in working capital to enhance firms' financial performance.

Our results contribute to existing academic literature by improving our understanding of how the impact of WCM on financial performance changes under different conditions. While prior studies provide extensive empirical evidence on the impact of WCM on financial performance, there is no evidence to demonstrate how the firms' ability to enhance financial performance through investment in working capital is influenced by contingent factors such as environmental, resource and management capabilities of the firm. We suggest that the relationship between WCM and firms' financial performance should be understood in the context these firmspecific characteristics. That is, the contingency framework helps to provide an understanding about the conditions under which investment in working capital can be an effective tool in enhancing firms' financial performance and which contingencies enhance or constrain firms' ability to achieve this objective.

The results also contribute to the dearth of research evidence on the relationship between WCM and financial performance in the UK. The few existing studies (Howorth \& Westhead 2003; Afrifa et. al., 2015;Tauringana \& Afrifa 2013) that have investigated this area have primarily focused on smaller firms. The results in respect of large companies may be different to those reported in respect of smaller companies given that large firms tend to use their market power to exploit their 'dominant' positions as buyers in competitive supply markets by taking 'extended' trade credit and thus leveraging their profit and cash-flow.

These results should, however, be interpreted in the light of a number of limitations. For example, the study sample is limited to non-financial companies listed on London stock exchange. As a result, we caution scholars against generalisation using the findings of this paper. Further, the study relied on only one measure for each of the three key contingent variables (environment, resources and management). It is possible that the use of different measures of the three contingent variables may yield different results.

\section{References:}


Adams, R. B., Almeida, H. and Ferreira, D. (2005) 'Powerful CEOs and their impact on corporate performance', Review of Financial Studies, pp. 1403-1432. doi:

10.1093/rfs/hhi030.

Afrifa, G;Tingbani, I. (2018) 'Working capital management, cash flow and SMEs ' performance', Int. J. Banking, Accounting and Finance, 9(1).

Afrifa, G., Tauringana, V. and Tingbani, I., 2015. 'Working capital management and performance of listed SMEs'. Journal of Small Business \& Entrepreneurship, 27 (6).

Afrifa, G. A. and Gyapong, E. (2017) 'Net trade credit: what are the determinants?', International Journal of Managerial Finance, 13(3), pp. 246-266. doi: 10.1108/IJMF12-2015-0222.

Aktas, N., Croci, E. and Petmezas, D. (2015) 'Is working capital management valueenhancing? Evidence from firm performance and investments', Journal of Corporate Finance, 30, pp. 98-113. doi: 10.1016/j.jcorpfin.2014.12.008.

de Almeida, J. R. and Eid, W. (2014) 'Access to finance, working capital management and company value: Evidences from Brazilian companies listed on BM\&FBOVESPA', Journal of Business Research, 67(5), pp. 924-934. doi: 10.1016/j.jbusres.2013.07.012.

Ambrosini, V., Bowman, C. and Collier, N. (2009) 'Dynamic capabilities: An exploration of how firms renew their resource base', British Journal of Management, 20(SUPP. 1). doi: 10.1111/j.1467-8551.2008.00610.x.

Arellano, M. and Bover, O. (1995) 'Another Look at the Instrumental Variable Estimation of Error-Component Models', Journal of econometrics, 68(1), pp. 29-52. doi: 10.1016/0304-4076(94)01642-D.

Autukaite, R. and Molay, E. (2011) 'CASH HOLDINGS , WORKING CAPITAL AND FIRM VALUE: EVIDENCE FROM FRANCE', SSRN Electronic Journal, 30, pp. 1-22. doi: 10.2139/ssrn.1836900.

Baños-Caballero, S., García-Teruel, P. J. and Martínez-Solano, P. (2010) 'Working capital management in SMEs', Accounting \& Finance, 50(3), pp. 511-527. doi: 10.1111/j.1467-629X.2009.00331.x.

Baños-Caballero, S., García-Teruel, P. J. and Martínez-Solano, P. (2012) 'How does working capital management affect the profitability of Spanish SMEs?', Small Business Economics, 39(2), pp. 517-529. doi: 10.1007/s11187-011-9317-8.

Bastos, R. and Pindado, J. (2013) 'Trade credit during a financial crisis: A panel data analysis', Journal of Business Research, 66(5), pp. 614-620. doi:

10.1016/j.jbusres.2012.03.015.

Battilana, J., Gilmartin, M., Sengul, M., Pache, A. C. and Alexander, J. A. (2010) 'Leadership competencies for implementing planned organisational change', The Leadership Quarterly, 21, pp. 422-438. doi: 10.1016/j.leaqua.2010.03.007.

Blundell, R. and Bond, S. (1998) 'Initial conditions and moment restrictions in dynamic panel data models', Journal of Econometrics, 87(1), pp. 115-143. doi: 10.1016/S0304-4076(98)00009-8.

Bruns Jr., W. J. and Waterhouse, J. H. (1975) 'Budgetary Control and Organization 
Structure', Journal of Accounting Research, 13(2), pp. 177-203. doi: $10.2307 / 2490360$.

Burrell, M. (1979) 'Burrell and Morgan ' s', Sociology The Journal Of The British Sociological Association, 3(4), pp. 380-381. Available at:

http://search.ebscohost.com/login.aspx?direct=true \&db=bth\&AN=5963638\&site=eho st-live.

Chenhall, R. H. (2003) 'Management control systems design within its organizational context: Findings from contingency-based research and directions for the future', Accounting, Organizations and Society, pp. 127-168. doi: 10.1016/S03613682(01)00027-7.

Combs, J. G., Ketchen, D. J., Perryman, A. A. and Donahue, M. S. (2007) 'The moderating effect of CEO power on the board composition-firm performance relationship', Journal of Management Studies, 44(8), pp. 1299-1323. doi: 10.1111/j.1467-6486.2007.00708.x.

D'aveni, R. A. (1989) 'The aftermath of organizational decline: A longitudinal study of the strategic and managerial characteristics of declining firms', Academy of Management Journal, 32(3), pp. 577-605. doi: 10.2307/256435.

Dahya, J. and Travlos, N. G. (2000) 'Does the one man show pay? Theory and evidence on the dual CEO revisited', European Financial Management, 6(1), p. 85. Available at: http://www.redi-

bw.de/db/ebsco.php/search.ebscohost.com/login.aspx\%3Fdirect\%3Dtrue\%26db\%3 Dbuh\%26AN\%3D3166559\%26site\%3Dehost-live.

Deloof, M. (2003) 'Does working capital management affects profitability of Belgian firms?', Journal of Business Finance and Accounting, 30(3), pp. 573-587.

Drazin, R. and Ven, A. H. Van De (2013) 'Alternative Forms of Fit in Contingency Theory Alternative Forms of Fit in Contingency Theory and', Administrative science quarterly, 30(4), pp. 514-539. doi: 10.2307/2392695.

Drobetz, W. and Grüninger, M. C. (2007) 'Corporate cash holdings: Evidence from Switzerland', Financial Markets and Portfolio Management, 21(3), pp. 293-324. doi: 10.1007/s11408-007-0052-8.

Dunn, P. (2004) 'The impact of insider power on fraudulent financial reporting', Journal of Management, 30(3), pp. 397-412. doi: 10.1016/j.jm.2003.02.004.

Enqvist, J., Graham, M. and Nikkinen, J. (2014) 'The impact of working capital management on firm profitability in different business cycles: Evidence from Finland', Research in International Business and Finance, 32. doi:

10.1016/j.ribaf.2014.03.005.

Ezzamel, M. (1990) 'The impact of environmental uncertainty, managerial autonomy and size on budget characteristics', Management Accounting Research, 1(3), pp. 181-197. doi: 10.1016/S1044-5005(90)70057-1.

Fama, E. F. and Jensen, M. C. (1983) 'Separation of Ownership and Control Separation of Ownership and Control', Journal of law and economics, 26(2), pp. 301-325. doi: 10.1086/467037.

Ferreira, A. and Otley, D. (2005) 'The design and use of management control 
systems : An extended framework for analysis', AAA 2006 Management Accounting Section Meeting, (October), pp. 1-54. doi: 10.2139/ssrn.682984.

Filbeck, G. and Krueger, T. M. (2005) 'An Analysis of Working Capital Management Results Across Industries', American Journal of Business, 20(2), pp. 11-20. doi: 10.1108/19355181200500007.

Forbes, D. P. . and Milliken, F. J. . (1999) 'Cognition and Corporate Governance : Understanding Boards of Directors as Strategic Decision-Making Groups Daniel P . Forbes ; Frances J . Milliken', Academy of Management Review, 24(3), pp. 489-505. doi: $10.2307 / 259138$.

Forbes, D. P. and Milliken, F. J. (2008) 'Cognition and corporate governance: Understanding boards of directors as strategic decision making groups', in The Value Creating Board: Corporate Governance and Organizational Behaviour, pp. 190-217. doi: 10.4324/9780203888711.

Gill, A. S. and Biger, N. (2013) 'The impact of corporate governance on working capital management efficiency of American manufacturing firms', Managerial Finance, 39(2), pp. 116-132. doi: 10.1108/03074351311293981.

Hambrick, D. C. and D'Aveni, R. a. (1992) 'Top Team Deterioration as Part of the Downward Spiral of Large Corporate Bankruptcies', Management Science, 38(10), pp. 1445-1466. doi: 10.1287/mnsc.38.10.1445.

Headd, B. (2003) 'Redefining Business Success: Distinguishing between Closure and Failure', Small Business Economics, pp. 51-61. doi: 10.1023/A:1024433630958.

Hill, M. D., Kelly, G. W. and Lockhart, G. B. (2012) 'Shareholder Returns from Supplying Trade Credit', Financial Management, 41(1), pp. 255-280. doi: 10.1111/j.1755-053X.2012.01198.x.

Hoopes, D. G. and Madsen, T. L. (2008) 'A capability-based view of competitive heterogeneity', Industrial and Corporate Change, 17(3), pp. 393-426. doi: 10.1093/icc/dtn008.

Howorth, C. and Westhead, P. (2003) 'The focus of working capital management in UK small firms', Management Accounting Research, pp. 94-111. doi: 10.1016/S1044-5005(03)00022-2.

Judson, R. A. and Owen, A. L. (1999) 'Estimating dynamic panel data models: a guide for macroeconomists', Economics Letters, 65(1), pp. 9-15. doi: 10.1016/S0165-1765(99)00130-5.

Kestens, K., Van Cauwenberge, P. and Bauwhede, H. Vander (2012) 'Trade credit and company performance during the 2008 financial crisis', Accounting and Finance, 52(4), pp. 1125-1151. doi: 10.1111/j.1467-629X.2011.00452.x.

Khoury, N. T., Smith, K. V and MacKay, P. I. (1999) 'Comparing working capital practices in Canada, the United States, and Australia: A note', Revue Canadienne des Sciences de l'Administration, 16(1), pp. 53-57. doi: 10.1016/10440283(91)90012-V.

Kieschnick, R., Laplante, M. and Moussawi, R. (2013) 'Working capital management and shareholders' wealth', Review of Finance, 17(5), pp. 1827-1852. doi:

10.1093/rof/rfs043. 
Knott, A. M. and Posen, H. E. (2005) 'Is failure good?', Strategic Management Journal, 26(7), pp. 617-641. doi: 10.1002/smj.470.

Kyereboah-Coleman, A. (2008) 'Corporate Governance and Firm Performance in Afica : A Dynamic Panel Data Analysis', Studies in Economics and Econometrics, 32(2), pp. 1-24. doi: 10.1111/j.1467-8683.2005.00419.x.

Love, I., Preve, L. A. and Sarria-Allende, V. (2007) 'Trade credit and bank credit: Evidence from recent financial crises', Journal of Financial Economics, 83(2), pp. 453-469. doi: 10.1016/j.jfineco.2005.11.002.

Luo, X., Kanuri, V. K. and Andrews, M. (2014) 'How does CEO tenure matter? the mediating role of firm-employee and firm-customer relationships', Strategic Management Journal, 35(4), pp. 492-511. doi: 10.1002/smj.2112.

Luthans, F. and Stewart, T. I. (1977) 'A general contingency theory of management', Academy of management review, 2(2), pp. 181-195. doi: 10.2307/257902.

Merchant, K. A. (1981) 'The Design of the Corporate Budgeting System : Influences on Managerial Behavior and Performance', The Accounting Review, 56(4), pp. 813829. doi: $10.2307 / 247203$.

Merchant, K. A. (1984) 'Influences on departmental budgeting: an empirical examination of a contingency model', Accounting, Organizations and Society, 9(34), pp. 291-307. doi: 10.1016/0361-3682(84)90013-8.

Mol, J. M. and Wijnberg, N. M. (2011) 'From Resources to Value and Back: Competition Between and Within Organizations', British Journal of Management, 22(1), pp. 77-95. doi: 10.1111/j.1467-8551.2010.00711.x.

Mollah, S. and Liljeblom, E. (2016) 'Governance and bank characteristics in the credit and sovereign debt crises - the impact of CEO power', Journal of Financial Stability, 27(September), pp. 59-73. doi: 10.1016/j.jfs.2016.09.003.

Nadiri, M. I. (1969) 'The Determinants of Trade Credit in the U.s. Total Manufacturing Sector', Econometrica (pre-1986), 37(3), p. 408. doi: 10.2307/1912790.

Ng, C., Smith, J. and Smith, R. (1999) 'Evidence on the determinants of credit terms used in interfirm trade', The Journal of Finance, 54(3), pp. 1109-1129. Available at: http://onlinelibrary.wiley.com/doi/10.1111/0022-1082.00138/abstract.

Nicholson, G. J. and Kiel, G. C. (2004) 'Breakthrough board performance: how to harness your board's intellectual capital[1]', Corporate Governance: The international journal of business in society, 4(1), pp. 5-23. doi: 10.1108/14720700410521925.

Nickell, S. (1999) 'Product markets and labour markets', Labour Economics, 6(1), pp. 1-20. doi: 10.1016/S0927-5371(99)00005-6.

Otley, D. (2016) 'The contingency theory of management accounting and control: 1980-2014', Management Accounting Research. Elsevier Ltd, 31, pp. 45-62. doi: 10.1016/j.mar.2016.02.001.

Otley, D. T. (1980) 'The contingency theory of management accounting:

Achievement and prognosis', Accounting, Organizations and Society, 5(4), pp. 413428. doi: 10.1016/0361-3682(80)90040-9. 
Paul, S. and Boden, R. (2008) 'The secret life of UK trade credit supply: Setting a new research agenda', The British Accounting Review, 40(3), pp. 272-281. doi: DOI: 10.1016/j.bar.2008.05.007.

Peel, M. J. and Wilson, N. (1996) 'Working Capital and Financial Management Practices in the Small Firm Sector', International Small Business Journal, 14(2), pp. 52-68. doi: 10.1177/0266242696142004.

Peel, M. J., Wilson, N. and Howorth, C. (2000) 'Late Payment and Credit Management in the Small Firm Sector: Some Empirical Evidence', International Small Business Journal, 18(2), pp. 17-37. doi: 10.1177/0266242600182001.

Peteraf, M. A. (1993) 'The cornerstones of competitive advantage: A resource-based view', Strategic Management Journal, 14(3), pp. 179-191. doi: 10.1002/smj.4250140303.

R. Ek ; S. Guerin (2011) 'Is there a right level of working capital?', Journal of Corporate Treasury Management, 4(2), pp. 137-149.

Ramiah, V., Zhao, Y., Moosa, I. and Graham, M. (2016) 'A behavioural finance approach to working capital management', European Journal of Finance, 22(8-9), pp. 662-687. doi: 10.1080/1351847X.2014.883549.

Rueda-Manzanares, A., Aragón-Correa, J. A. and Sharma, S. (2008) 'The influence of stakeholders on the environmental strategy of service firms: The moderating effects of complexity, uncertainty and munificence', British Journal of Management, 19(2), pp. 185-203. doi: 10.1111/j.1467-8551.2007.00538.x.

Spanos, Y. E., Zaralis, G. and Lioukas, S. (2004) 'Strategy and industry effects on profitability: Evidence from Greece’, Strategic Management Journal, 25(2), pp. 139165. doi: 10.1002/smj.369.

Tauringana, V. and Afrifa, G. (2013) 'The relative importance of working capital management and its components to SMEs' profitability', Journal of Small Business and Enterprise Development, 20(3), pp. 453-469. doi: 10.1108/jsbed-12-2011-0029.

Thorgren, S., Wincent, J. and Anokhin, S. (2010) 'The importance of compensating strategic network board members for network performance: A contingency approach', British Journal of Management, 21(1), pp. 131-151. doi: 10.1111/j.14678551.2009.00674.x.

Venkatraman, N. and Prescott, J. E. (1990) 'Environment-strategy coalignment: An empirical test of its performance implications', Strategic Management Journal, 11(1), pp. 1-23. doi: 10.1002/smj.4250110102.

Wadongo, B. and Abdel-Kader, M. (2014) 'Contingency theory, performance management and organisational effectiveness in the third sector: A theoretical framework', International Journal of Productivity and Performance Management, 63(6), pp. 680-703. doi: 10.1108/IJPPM-09-2013-0161.

Wu, S., Quan, X. and Xu, L. (2011) 'CEO power, disclosure quality and the variability of firm performance', Nankai Business Review International, 2(1), pp. 79-97. doi: 10.1108/20408741111113510.

Zalata, A.M, Tauringana, V and Tingbani, I. (2018) ' Audit committee financial expertise, gender, and earnings management: Does gender of the financial expert 
matter?', International review of financial analysis, 55, pp. 170-183.

Zona, F., Zattoni, A. and Minichilli, A. (2013) 'A Contingency Model of Boards of Directors and Firm Innovation: The Moderating Role of Firm Size', British Journal of Management, 24(3), pp. 299-315. doi: 10.1111/j.1467-8551.2011.00805.x. 
Table 1: Summary of variables, calculations and definitions

Variable Acronym Description

Dependent variable

Return on assets

Tobin's Q Ratio

Independent variable

\section{Cash Conversion Cycle}

Investment in working capital

CCC

WCM

Control Variables

Current ratio

Annual Sales Growth

Company Age

Tangible Fixed Assets

Financial Leverage

Cash Flow

ROA

AGE

FLEV
QRATIO

Ratio of profit before interest and tax to total assets.

Ratio of total assets minus book value of equity plus market value of equity to total assets.

GROWTH

ATAN

CFLOW

$$
\mathrm{CCC}=((\text { Total inventories }) /(\text { cost of sales }) * 365)+((\text { Accounts receivable }) / \text { sales } * 365)
$$$$
\text { - ((Accounts payable)/purchases } * 365)
$$

Net operating working capital (inventories plus receivables minus accounts payable) scaled by sales

current assets divided by current liabilities at the end of the financial

Percentage change in sales revenue over the previous year.

Number of years between incorporation and the calendar year end of each firm.

Fixed assets as a percentage of total assets.

Total debt as a percentage of total assets.

Operating income before depreciation and amortisation minus interest expense and income tax expense scaled total assets. 
Table 2: Descriptive statistics

The table provides the sample characteristics based on a sample of 802 UK quoted firms over the period 2005-2014. All variables are defined in Table 1.

\begin{tabular}{lllcccr}
\hline Variables & Obs. & Mean & Std Dev & perc 10 & Median & perc 90 \\
QRATIO(ratio) & 6,424 & 1.4921 & 1.3089 & 0.9709 & 1.2143 & 2.0178 \\
ROA(ratio) & 6,424 & 5.1093 & 11.0232 & 1.0298 & 8.2627 & 16.7553 \\
CCC $_{\text {t-1 }}$ (days) & 6,424 & 65.901 & 192.610 & 14.335 & 72.446 & 219.452 \\
GROWTH (\%) & 6,424 & 12.696 & 2.651 & 9.595 & 12.479 & 16.300 \\
AGE(years) & 6,332 & 19.7312 & 17.1512 & 8.9871 & 15.6013 & 52.0187 \\
ATAN (\%) & 6,113 & 37.1788 & 35.4094 & 3.0187 & 26.2038 & 69.2758 \\
FLEV (\%) & 6,008 & 11.3980 & 13.6211 & 0.0000 & 5.7109 & 29.6456 \\
CR(ratio) & 6,013 & 1.590 & 2.330 & 0.000 & 1.280 & 3.190
\end{tabular}


Table 3: Correlation Matrix.

The table provides the Pearson correlation coefficients based on a sample of 802 UK quoted firms over the period 2004-2014.

All variables are defined in Table 1. ${ }^{* \star *},{ }^{* *}$ and * represent coefficients significant at the $1 \%, 5 \%$ and $10 \%$ levels

correspondingly (two-tailed tests).

\begin{tabular}{|c|c|c|c|c|c|c|c|c|c|c|}
\hline Variables & QRATIO & ROA & WCM & CFLOW & GROWTH & AGE & SIZE & ATAN & LEV & CR \\
\hline QRATIO & 1 & & & & & & & & & \\
\hline \multirow[t]{2}{*}{ ROA } & 0.3708 & 1 & & & & & & & & \\
\hline & 0.0000 & & & & & & & & & \\
\hline \multirow[t]{2}{*}{ WCM } & -0.0315 & -0.1365 & 1 & & & & & & & \\
\hline & 0.0000 & 0.0000 & & & & & & & & \\
\hline \multirow[t]{2}{*}{ CFLOW } & 0.2201 & 0.2238 & 0.0768 & 1 & & & & & & \\
\hline & 0.0000 & 0.0000 & 0.0000 & & & & & & & \\
\hline \multirow[t]{2}{*}{ GROWTH } & 0.1570 & 0.0381 & 0.0585 & 0.1472 & 1 & & & & & \\
\hline & 0.0000 & 0.0000 & 0.0000 & 0.0000 & & & & & & \\
\hline \multirow[t]{2}{*}{ AGE } & 0.1380 & 0.1856 & 0.2064 & 0.2777 & 0.1817 & 1 & & & & \\
\hline & 0.0000 & 0.0000 & 0.0000 & 0.0000 & 0.0000 & & & & & \\
\hline \multirow[t]{2}{*}{ SIZE } & 0.0583 & 0.1411 & -0.066 & -0.028 & -0.0708 & 0.1094 & 1 & & & \\
\hline & 0.0000 & 0.0000 & 0.0000 & 0.0000 & 0.0000 & 0.0000 & & & & \\
\hline \multirow[t]{2}{*}{ ATAN } & -0.1927 & -0.0033 & 0.0499 & 0.0645 & 0.0740 & 0.2390 & 0.1802 & 1 & & \\
\hline & 0.0000 & 0.0000 & 0.0000 & 0.0000 & 0.0000 & 0.0000 & 0.0000 & & & \\
\hline \multirow[t]{2}{*}{ FLEV } & -0.1673 & -0.1099 & 0.0701 & -0.114 & -0.0536 & -0.206 & -0.239 & -0.2323 & 1 & \\
\hline & 0.0000 & 0.0000 & 0.0000 & 0.0000 & 0.0000 & 0.0000 & 0.0000 & 0.0000 & & \\
\hline \multirow[t]{2}{*}{ CR } & 0.129 & 0.0417 & 0.157 & 0.0065 & -0.0181 & 0.0230 & -0.073 & -0.0118 & -0.023 & 1 \\
\hline & 0.0000 & 0.0000 & 0.0000 & 0.0000 & 0.0000 & 0.0000 & 0.0000 & 0.0000 & 0.0000 & \\
\hline
\end{tabular}


Table 4: Working Capital Management and Firms' Financial Performance

This table reports a generalized method of moments (GMM) first-difference estimation on the relationship between WCM and firm financial performance for across 802 UK quoted firms over the period 2004-2014, with $t$-statistics (reported in parentheses). The dependent variable is the return on assets and Tobin's Q. All variables are defined in Table 1. AR1 (AR2) is a test for first- (second-) order serial correlation in the firstdifferenced residuals, asymptotically distributed as $N(0,1)$ under the null of no serial. Hansen test is a test of over-identifying restrictions distributed asymptotically under null hypothesis of validity of instruments as Chisquared. The degrees of freedom are given in parenthesis. Instruments include AGEi,t-2; CRi,t-2 FLEVi,t-2; GROWTH $\mathrm{H}_{\mathrm{i}-\mathrm{t}-\text {; }}$ and further lags. Year dummies and time dummies interacted with industry dummies were always included as regressors and as instruments. ${ }^{* \star \star},{ }^{\star \star}$ and ${ }^{*}$ represent coefficients significant at the $1 \%, 5 \%$ and $10 \%$ levels correspondingly (two-tailed tests).

\begin{tabular}{|c|c|c|c|c|}
\hline DEPENDENT & $(1)$ & (2) & (3) & (4) \\
\hline VARIABLE & $\mathrm{ROA}$ & QRATIO & ROA & QRATIO \\
\hline ROA & $\begin{array}{c}0.3950 * \star * \\
(18.58)\end{array}$ & & $\begin{array}{c}0.3841^{\star \star *} \\
(46.69)\end{array}$ & \\
\hline QRATIO & & $\begin{array}{c}0.7750 * \star \star \\
(20.79)\end{array}$ & & $\begin{array}{c}0.9081^{* * *} \\
(64.87)\end{array}$ \\
\hline WCM & $\begin{array}{c}-0.0061 * * * \\
(-5.54)\end{array}$ & $\begin{array}{c}-1.1020 \text { *** } \\
(-4.86)\end{array}$ & $\begin{array}{c}-0.0210^{* * *} \\
(-26.99)\end{array}$ & $\begin{array}{c}-0.0920^{* \star *} \\
(-21.34)\end{array}$ \\
\hline AGE & & & $\begin{array}{c}-0.0908^{\star \star \star} \\
(-35.22)\end{array}$ & $\begin{array}{c}-0.0008^{\star \star \star} \\
(-4.68)\end{array}$ \\
\hline CR & & & $\begin{array}{c}-0.0072^{* \star *} \\
(-16.07)\end{array}$ & $\begin{array}{c}-0.1352^{\star \star \star} \\
(-29.49)\end{array}$ \\
\hline FLEV & & & $\begin{array}{c}-0.0149 * * * \\
(-98.36)\end{array}$ & $\begin{array}{c}-0.0423^{\star \star \star} \\
(-22.13)\end{array}$ \\
\hline ATAN & & & $\begin{array}{c}-0.0018^{* \star *} \\
(-9.09)\end{array}$ & $\begin{array}{c}-0.0088^{\star * \star} \\
(-6.16)\end{array}$ \\
\hline GROWTH & & & $\begin{array}{l}0.0001^{* \star *} \\
(4.36)\end{array}$ & $\begin{array}{c}-0.0002^{\star \star \star} \\
(-9.52)\end{array}$ \\
\hline INDUSTRY & YES & YES & YES & YES \\
\hline YEAR & YES & YES & YES & YES \\
\hline OBSERVATIONS & 5,845 & 5,845 & 5,845 & 5,845 \\
\hline $\begin{array}{l}\text { HANSEN TEST } \\
\text { (P) }\end{array}$ & 0.303 & 0.440 & 0.332 & 0.246 \\
\hline AR1(p) & 0.000 & 0.008 & 0.000 & 0.000 \\
\hline AR2(p) & 0.342 & 0.796 & 0.185 & 0.407 \\
\hline
\end{tabular}


Table 5: Working Capital Management, Environmental Conditions and Firms' Financial Performance

This table reports a generalized method of moments (GMM) first-difference estimation on the relationship between WCM and firm financial performance for across 802 UK quoted firms over the period 2004-2014, with $t$-statistics (reported in parentheses). The dependent variable is the return on assets and Tobin's Q. All variables are defined in Table 1. AR1 (AR2) is a test for first- (second-) order serial correlation in the first-differenced residuals, asymptotically distributed as $N(0,1)$ under the null of no serial. Hansen test is a test of over-identifying restrictions distributed asymptotically under null hypothesis of validity of instruments as Chi-squared. The degrees of freedom are given in parenthesis. Instruments include AGEi, t-2; CRi,t-2 FLEVi,t-2; GROWTHi,t-2; and further lags. Year dummies and time dummies interacted with industry dummies were always included as regressors and as instruments. ${ }^{* * *},{ }^{* *}$ and $*$ represent coefficients significant at the $1 \%, 5 \%$ and $10 \%$ levels correspondingly (two-tailed tests).

\begin{tabular}{|c|c|c|c|c|}
\hline DEPENDENT & $(1)$ & $(2)$ & (3) & $(4)$ \\
\hline VARIABLE & ROA & ROA & QRATIO & QRATIO \\
\hline ROA & $\begin{array}{c}0.307^{* * *} \\
(13.29)\end{array}$ & $\begin{array}{c}0.387^{* * *} \\
(51.03)\end{array}$ & & \\
\hline QRATIO & & & $\begin{array}{c}0.996 * \star \star \\
(50.01)\end{array}$ & $\begin{array}{c}0.909 * * * \\
(61.25)\end{array}$ \\
\hline WCM & $\begin{array}{c}-0.0177^{*} \\
(-1.83)\end{array}$ & $\begin{array}{c}-0.0208^{\star \star \star} \\
(-26.54)\end{array}$ & $\begin{array}{c}0.00648 \\
(0.94)\end{array}$ & $\begin{array}{c}0.187^{* * *} \\
(30.78)\end{array}$ \\
\hline AGE & $\begin{array}{c}-0.223^{\star \star \star} \\
(-7.99)\end{array}$ & $\begin{array}{c}-0.0871^{\star * \star} \\
(-36.01)\end{array}$ & $\begin{array}{c}0.000280 \\
(0.89)\end{array}$ & $\begin{array}{c}-0.00134^{\star \star \star} \\
(-9.09)\end{array}$ \\
\hline CR & $\begin{array}{c}-0.0159 * \star \star \\
(-3.76)\end{array}$ & $\begin{array}{c}-0.00738^{\star \star *} \\
(-17.12)\end{array}$ & $\begin{array}{c}-0.0423^{\star * \star} \\
(-4.46)\end{array}$ & $\begin{array}{c}-0.132^{\star \star \star} \\
(-33.25)\end{array}$ \\
\hline CRISIS & & $\begin{array}{c}-0.0146^{\star \star \star} \\
(-36.17)\end{array}$ & & $\begin{array}{c}-0.0460 * \star \star \\
(-14.84)\end{array}$ \\
\hline COMPETITION & $\begin{array}{c}0.00494^{* * *} \\
(7.18)\end{array}$ & & $\begin{array}{c}0.00451^{\star *} \\
(2.50)\end{array}$ & \\
\hline FLEV & $\begin{array}{c}-0.00804 \\
(-1.00)\end{array}$ & $\begin{array}{c}-0.0153^{\star * *} \\
(-105.09)\end{array}$ & $\begin{array}{c}-0.00608 \\
(-0.88)\end{array}$ & $\begin{array}{c}-0.0421^{\star \star \star} \\
(-27.50)\end{array}$ \\
\hline ATAN & $\begin{array}{c}0.000334 \\
(0.29)\end{array}$ & $\begin{array}{c}-0.00179 * * * \\
(-8.80)\end{array}$ & $\begin{array}{c}-0.00960 \\
(-1.61)\end{array}$ & $\begin{array}{c}-0.0168^{\star \star *} \\
(-13.82)\end{array}$ \\
\hline GROWTH & $\begin{array}{c}0.0151^{\star * \star} \\
(7.72)\end{array}$ & $\begin{array}{c}-0.000934^{\star * *} \\
(-66.29)\end{array}$ & $\begin{array}{c}0.00401^{\star *} \\
(2.10)\end{array}$ & $\begin{array}{c}-0.000421^{\star * \star} \\
(-19.93)\end{array}$ \\
\hline INDUSTRY & YES & YES & YES & YES \\
\hline YEAR & YES & YES & YES & YES \\
\hline OBSERVATIONS & 5,845 & 5,845 & 5,845 & 5,845 \\
\hline $\begin{array}{l}\text { HANSEN TEST } \\
\text { (P) }\end{array}$ & 0.237 & 0.339 & 0.442 & 0.391 \\
\hline AR1 (p) & 0.000 & 0.000 & 0.000 & 0.000 \\
\hline AR2 (p) & 0.299 & 0.184 & 0.624 & 0.383 \\
\hline
\end{tabular}


Table 6: Working Capital Management, Environmental Conditions and Firms' Financial Performance

This table reports a generalized method of moments (GMM) first-difference estimation on the relationship between WCM and firm financial performance for across 802 UK quoted firms over the period 2004-2014, with $t$-statistics (reported in parentheses). The dependent variable is the return on assets and Tobin's Q. All variables are defined in Table 1. AR1 (AR2) is a test for first- (second-) order serial correlation in the first-differenced residuals, asymptotically distributed as $N(0,1)$ under the null of no serial. Hansen test is a test of over-identifying restrictions distributed asymptotically under null hypothesis of validity of instruments as Chi-squared. The degrees of freedom are given in parenthesis. Instruments include $\mathrm{AGE}_{\mathrm{i}, \mathrm{t}-2} ; \mathrm{CR}_{\mathrm{i}, \mathrm{t}-2} \mathrm{FLEV} \mathrm{i}, \mathrm{t}-2$; GROWTH $\mathrm{H}_{\mathrm{i},-2}$; and further lags. Year dummies and time dummies interacted with industry dummies were always included as regressors and as instruments. ${ }^{* * *},{ }^{* *}$ and $*$ represent coefficients significant at the $1 \%, 5 \%$ and $10 \%$ levels correspondingly (two-tailed tests).

\begin{tabular}{|c|c|c|c|c|}
\hline DEPENDENT & (1) & $(2)$ & (3) & (4) \\
\hline VARIABLE & ROA & QRATIO & ROA & QRATIO \\
\hline ROA & $\begin{array}{c}0.326^{\star \star \star} \\
(14.00)\end{array}$ & $\begin{array}{l}0.386^{\star \star *} \\
(317.87)\end{array}$ & & \\
\hline QRATIO & & & $\begin{array}{c}0.995^{\star \star \star} \\
(49.49)\end{array}$ & $\begin{array}{c}0.950 * * * \\
(35.78)\end{array}$ \\
\hline WCM & $\begin{array}{c}-0.123^{\star \star \star} \\
(-4.42)\end{array}$ & $\begin{array}{c}-0.0300^{* * *} \\
(-37.95)\end{array}$ & $\begin{array}{c}-0.129 * * * \\
(-2.77)\end{array}$ & $\begin{array}{c}-0.157^{* * *} \\
(-19.35)\end{array}$ \\
\hline AGE & $\begin{array}{c}-0.182^{\star * \star} \\
(-4.99)\end{array}$ & $\begin{array}{c}-0.0925^{\star \star \star} \\
(-24.71)\end{array}$ & $\begin{array}{c}-0.117^{* *} \\
(-2.06)\end{array}$ & $\begin{array}{c}0.000508^{*} \\
(1.86)\end{array}$ \\
\hline CR & $\begin{array}{c}-0.0184^{\star \star \star} \\
(-3.82)\end{array}$ & $\begin{array}{c}-0.00739 * * * \\
(-13.28)\end{array}$ & $\begin{array}{c}-0.0586^{\star * \star} \\
(-4.66)\end{array}$ & $\begin{array}{c}-0.124^{\star \star \star} \\
(-26.43)\end{array}$ \\
\hline COMPETITION & $\begin{array}{l}0.0593^{* * *} \\
\quad(6.15)\end{array}$ & & $\begin{array}{c}0.0721^{\star * *} \\
(3.50)\end{array}$ & \\
\hline CRISIS & & $\begin{array}{c}-0.135^{\star \star \star} \\
(-12.61)\end{array}$ & & $\begin{array}{c}-0.354^{\star \star \star} \\
(-3.24)\end{array}$ \\
\hline WCM x COMPETITION & $\begin{array}{c}0.0474^{\star \star \star} \\
(0.46)\end{array}$ & & $\begin{array}{c}0.059 * * \star \\
(0.06)\end{array}$ & \\
\hline WCMt-1 $\times$ Crisis & & $\begin{array}{c}0.0302^{* * *} \\
(14.05)\end{array}$ & & $\begin{array}{l}0.0819 * \star \star \\
(3.62)\end{array}$ \\
\hline FLEV & $\begin{array}{c}-0.00609 \\
(-0.89)\end{array}$ & $\begin{array}{c}-0.0159 * * * \\
(-61.51)\end{array}$ & $\begin{array}{c}-0.0203 \\
(-1.33)\end{array}$ & $\begin{array}{c}-0.0539 * \star * \\
(-14.51)\end{array}$ \\
\hline ATAN & $\begin{array}{c}-0.000586 \\
(-0.52)\end{array}$ & $\begin{array}{c}0.00189 * \star \star \\
(5.85)\end{array}$ & $\begin{array}{c}0.00817 \\
(1.15)\end{array}$ & $\begin{array}{c}-0.00287 \\
(-1.22)\end{array}$ \\
\hline GROWTH & $\begin{array}{c}0.0142^{\star \star \star} \\
(5.62)\end{array}$ & $\begin{array}{c}-0.000959 * \star \star \\
(-64.47)\end{array}$ & $\begin{array}{l}0.00392^{*} \\
(1.76)\end{array}$ & $\begin{array}{l}0.000422^{\star * \star} \\
\quad(14.83)\end{array}$ \\
\hline INDUSTRY & YES & YES & YES & YES \\
\hline YEAR & YES & YES & YES & YES \\
\hline OBSERVATIONS & 5,845 & 5,845 & 5,845 & 5,845 \\
\hline HANSEN TEST $(p)$ & 0.168 & 0.120 & 0.161 & 0.210 \\
\hline AR1 (p) & 0.000 & 0.000 & 0.000 & 0.000 \\
\hline AR2 (p) & 0.328 & 0.208 & 0.504 & 0.731 \\
\hline
\end{tabular}


Table 7: Working Capital Management, Resource Capability and Firms' Financial Performance

This table reports a generalized method of moments (GMM) first-difference estimation on the relationship between WCM and firm financial performance for across 802 UK quoted firms over the period 2004-2014, with $t$-statistics (reported in parentheses). The dependent variable is the return on assets and Tobin's Q. All variables are defined in Table 1. AR1 (AR2) is a test for first- (second-) order serial correlation in the first-differenced residuals, asymptotically distributed as $N(0,1)$ under the null of no serial. Hansen test is a test of over-identifying restrictions distributed asymptotically under null hypothesis of validity of instruments as Chi-squared. The degrees of freedom are given in parenthesis. Instruments include $\mathrm{AGE}_{\mathrm{i}, \mathrm{t}-2} ; \mathrm{CR}_{\mathrm{i}, \mathrm{t}-2} \mathrm{FLEV} \mathrm{i}, \mathrm{t}-2$; GROWTH $\mathrm{H}_{\mathrm{i},-2}$; and further lags. Year dummies and time dummies interacted with industry dummies were always included as regressors and as instruments. ${ }^{* * *},{ }^{* *}$ and $*$ represent coefficients significant at the $1 \%, 5 \%$ and $10 \%$ levels correspondingly (two-tailed tests).

\begin{tabular}{|c|c|c|c|c|}
\hline & $(1)$ & $(2)$ & $(3)$ & $(4)$ \\
\hline & ROA & QRATIO & ROA & QRATIO \\
\hline \multirow[t]{2}{*}{ ROA } & $0.373^{\star \star \star}$ & & $0.370 * \star \star$ & \\
\hline & $(22.80)$ & & $(14.09)$ & \\
\hline \multirow[t]{2}{*}{ QRATIO } & & $0.989 * \star \star$ & & $0.992^{\star \star \star}$ \\
\hline & & $(98.91)$ & & $(78.52)$ \\
\hline \multirow[t]{2}{*}{ WCM } & $-0.0208^{* \star *}$ & $-0.0229 * * \star$ & $-0.0294^{\star \star \star}$ & $-0.0313^{\star \star *}$ \\
\hline & $(-27.44)$ & $(-11.20)$ & $(-33.42)$ & $(-10.04)$ \\
\hline \multirow[t]{2}{*}{ WCM x SIZE } & & & $0.0276^{\star \star \star}$ & $0.006^{\star * \star}$ \\
\hline & & & $(12.12)$ & $(0.03)$ \\
\hline \multirow[t]{2}{*}{ AGE } & $-0.100^{\star \star \star}$ & $-0.001^{\star \star \star}$ & $-0.102^{\star \star \star}$ & $-0.001^{\star \star \star}$ \\
\hline & $(-34.07)$ & $(-5.51)$ & $(-23.69)$ & $(-4.08)$ \\
\hline \multirow[t]{2}{*}{ CR } & $-0.00517^{\star \star \star}$ & $-0.0765^{\star * *}$ & $-0.007^{\star \star \star}$ & $-0.0939 * * \star$ \\
\hline & $(-11.56)$ & $(-10.46)$ & $(-6.97)$ & $(-11.49)$ \\
\hline \multirow[t]{2}{*}{ SIZE } & $0.0395^{\star \star \star}$ & $0.0047^{\star \star \star}$ & $0.0612^{\star \star \star}$ & $0.0716^{*}$ \\
\hline & $(7.68)$ & $(6.39)$ & $(7.10)$ & $(1.96)$ \\
\hline \multirow[t]{2}{*}{ FLEV } & $-0.0141^{* * *}$ & $-0.0073^{\star * *}$ & $-0.0138^{\star * *}$ & $-0.0123^{\star \star \star}$ \\
\hline & $(-81.70)$ & $(-6.80)$ & $(-47.32)$ & $(-5.84)$ \\
\hline \multirow[t]{2}{*}{ ATAN } & $-0.000711^{\star \star \star}$ & $-0.0066^{\star \star \star}$ & $-0.000681^{\star *}$ & $-0.0082^{\star \star \star}$ \\
\hline & $(-2.76)$ & $(-3.29)$ & $(-2.29)$ & $(-3.58)$ \\
\hline \multirow[t]{2}{*}{ GROWTH } & 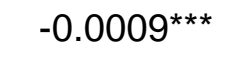 & $0.0003^{\star \star *}$ & $-0.001^{\star * \star}$ & $0.0004^{\star * \star}$ \\
\hline & $(-61.35)$ & $(10.71)$ & $(-51.56)$ & $(10.70)$ \\
\hline INDUSTRY & YES & YES & YES & YES \\
\hline OBSERVATIONS & 5,845 & 5,845 & 5,845 & 5,845 \\
\hline YEAR & YES & YES & YES & YES \\
\hline \multicolumn{5}{|l|}{ HANSEN TEST } \\
\hline (p) & 0.143 & 0.213 & 0.304 & 0.146 \\
\hline AR1 (p) & 0.000 & 0.006 & 0.000 & 0.000 \\
\hline AR2 (p) & 0.314 & 0.102 & 0.379 & 0.142 \\
\hline
\end{tabular}


Table 8: Working Capital Management, management capability and Firm Financial Performance

This table reports a generalized method of moments (GMM) first-difference estimation on the relationship between WCM and firm financial performance for across 802 UK quoted firms over the period 2004-2014, with $t$-statistics (reported in parentheses). The dependent variable is the return on assets and Tobin's Q. All variables are defined in Table 1. AR1 (AR2) is a test for first- (second-) order serial correlation in the first-differenced residuals, asymptotically distributed as $N(0,1)$ under the null of no serial. Hansen test is a test of over-identifying restrictions distributed asymptotically under null hypothesis of validity of instruments as Chi-squared. The degrees of freedom are given in parenthesis. Instruments include $\mathrm{AGE}_{\mathrm{i}, \mathrm{t}-2}$; $\mathrm{CR}_{\mathrm{i}, \mathrm{t}-2} \mathrm{FLEV} \mathrm{i}, \mathrm{t}-2$; GROWTH $\mathrm{H}_{\mathrm{i},-2}$; and further lags. Year dummies and time dummies interacted with industry dummies were always included as regressors and as instruments. ${ }^{\star \star *}, * \star$ and * represent coefficients significant at the $1 \%, 5 \%$ and $10 \%$ levels correspondingly (two-tailed tests).

\begin{tabular}{|c|c|c|c|c|}
\hline & (1) & $(2)$ & (3) & $(4)$ \\
\hline & ROA & QRATIO & ROA & QRATIO \\
\hline ROA & $\begin{array}{l}0.373^{\star * \star} \\
(21.90)\end{array}$ & & $\begin{array}{c}0.370^{\star \star \star} \\
(14.90)\end{array}$ & \\
\hline QRATIO & & $\begin{array}{l}0.989 * \star \star \\
(977.91)\end{array}$ & & $\begin{array}{l}0.992^{\star \star \star} \\
(787.52)\end{array}$ \\
\hline WCM & $\begin{array}{c}-0.0208^{\star \star \star} \\
(-27.44)\end{array}$ & $\begin{array}{c}-0.0229 * \star \star \\
(-11.20)\end{array}$ & $\begin{array}{c}-0.0294^{\star \star \star} \\
(-33.42)\end{array}$ & $\begin{array}{c}-0.0313^{\star * *} \\
(-10.04)\end{array}$ \\
\hline $\mathrm{WCM} \times \mathrm{M}$ & & & $\begin{array}{c}0.0276^{\star * *} \\
(12.12)\end{array}$ & $\begin{array}{c}0.064^{\star *} \\
(0.03)\end{array}$ \\
\hline AGE & $\begin{array}{c}0.0998^{\star \star \star} \\
(33.93)\end{array}$ & $\begin{array}{c}-0.000633^{\star \star \star} \\
(-5.51)\end{array}$ & $\begin{array}{c}0.101^{\star \star *} \\
(23.49)\end{array}$ & $\begin{array}{c}-0.000507^{\star \star \star} \\
(-4.08)\end{array}$ \\
\hline CR & $\begin{array}{c}-0.00517^{\star * *} \\
(-11.56)\end{array}$ & $\begin{array}{c}-0.0765^{\star \star \star} \\
(-10.46)\end{array}$ & $\begin{array}{c}-0.00661^{\star \star \star} \\
(-6.97)\end{array}$ & $\begin{array}{c}-0.0939 * \star \star \\
(-11.49)\end{array}$ \\
\hline M & $\begin{array}{l}0.0395^{\star \star \star} \\
(7.68)\end{array}$ & $\begin{array}{c}0.0458^{*} \\
(1.76)\end{array}$ & $\begin{array}{l}0.0612^{\star \star \star} \\
(7.10)\end{array}$ & $\begin{array}{c}0.0717^{*} \\
(1.96)\end{array}$ \\
\hline FLEV & $\begin{array}{c}-0.0141^{\star \star *} \\
(-81.70)\end{array}$ & $\begin{array}{c}-0.00729^{\star \star \star} \\
(-6.80)\end{array}$ & $\begin{array}{c}-0.0138^{\star \star \star} \\
(-47.32)\end{array}$ & $\begin{array}{c}-0.0123^{\star \star \star} \\
(-5.84)\end{array}$ \\
\hline ATAN & $\begin{array}{c}-0.000711^{\star \star \star} \\
(-2.76)\end{array}$ & $\begin{array}{c}-0.00655^{\star \star \star} \\
(-3.29)\end{array}$ & $\begin{array}{c}-0.000681^{\star *} \\
(-2.29)\end{array}$ & $\begin{array}{c}-0.00820^{\star \star \star} \\
(-3.58)\end{array}$ \\
\hline GROWTH & $-0.000857^{* \star *}$ & $0.000306^{\star * *}$ & $-0.000898^{* * *}$ & $0.000443^{\star * *}$ \\
\hline FLEV & $\begin{array}{l}(-61.35) \\
(-15.08)\end{array}$ & $\begin{array}{l}(10.71) \\
(-9.58)\end{array}$ & $\begin{array}{l}(-51.56) \\
(-11.65)\end{array}$ & $\begin{array}{l}(10.70) \\
(-6.72)\end{array}$ \\
\hline OBSERVATIONS & 5,845 & 5,845 & 5,845 & 5,845 \\
\hline INDUSTRY & YES & YES & YES & YES \\
\hline $\begin{array}{l}\text { YEAR } \\
\text { HANSEN TEST }\end{array}$ & YES & YES & YES & YES \\
\hline (p) & 0.386 & 0.260 & 0.330 & 0.438 \\
\hline AR1 (p) & 0.000 & 0.000 & 0.000 & 0.000 \\
\hline AR2 (p) & 0.966 & 0.101 & 0.764 & 0.28 \\
\hline
\end{tabular}


Table 9: Alternative measure of Working Capital Management on Firms' Financial Performance

This table reports a generalized method of moments (GMM) first-difference estimation on the relationship between working capital management measured by the cash conversion cycle (CCC) and firms' financial performance for across 802 UK quoted firms over the period 2004-2014, with $t$-statistics (reported in parentheses). The dependent variable is the return on assets and Tobin's Q. All variables are defined in Table 1. AR1 (AR2) is a test for first- (second-) order serial correlation in the first-differenced residuals, asymptotically distributed as $N(0,1)$ under the null of no serial. Hansen test is a test of over-identifying restrictions distributed asymptotically under null hypothesis of validity of instruments as Chi-squared. The degrees of freedom are given in parenthesis. Instruments include AGE $E_{i,-2}$; CRi,-2 FLEVi,t-2; GROWTHi,t-2; and further lags. Year dummies and time dummies interacted with industry dummies were always included as regressors and as instruments. ${ }^{* * *},{ }^{* *}$ and ${ }^{*}$ represent coefficients significant at the $1 \%, 5 \%$ and $10 \%$ levels correspondingly (two-tailed tests).

\begin{tabular}{|c|c|c|c|c|c|c|c|c|}
\hline & (1) & $(2)$ & (3) & $(4)$ & $(5)$ & (6) & $(7)$ & $(8)$ \\
\hline & ROA & $\mathrm{ROA}$ & QRATIO & QRATIO & ROA & QRATIO & ROA & QRATIO \\
\hline ROA & $\begin{array}{c}0.336^{\star \star \star} \\
(35.34)\end{array}$ & $\begin{array}{c}0.386^{\star \star *} \\
(31.87)\end{array}$ & & & $\begin{array}{l}0.358^{\star \star \star} \\
(157.83)\end{array}$ & & $\begin{array}{l}0.391^{\star * *} \\
(136.15)\end{array}$ & \\
\hline QRATIO & & & $\begin{array}{l}0.79 * \star \star \\
(30.17)\end{array}$ & $\begin{array}{c}0.700^{\star \star \star} \\
(47.34)\end{array}$ & & $\begin{array}{c}0.762^{\star \star \star} \\
(59.05)\end{array}$ & & $\begin{array}{l}0.77^{\star * *} \\
(69.71)\end{array}$ \\
\hline $\mathrm{CCC}$ & $\begin{array}{c}-0.0279 * \star \\
(-2.52)\end{array}$ & 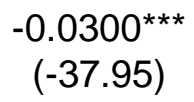 & $\begin{array}{c}-0.00125 \\
(-1.09)\end{array}$ & $\begin{array}{c}-0.0011^{\star \star *} \\
(-7.94)\end{array}$ & $\begin{array}{c}-0.00105^{\star \star \star} \\
(-14.96)\end{array}$ & $\begin{array}{c}-0.00032^{\star \star *} \\
(-7.31)\end{array}$ & $\begin{array}{c}-0.00128^{* \star \star} \\
(-13.65)\end{array}$ & $\begin{array}{c}-0.0004^{\star \star *} \\
(-12.62)\end{array}$ \\
\hline COMPETITION & $\begin{array}{c}0.0136^{\star \star \star} \\
(7.66)\end{array}$ & & $\begin{array}{c}0.0478^{\star * \star} \\
(6.94)\end{array}$ & & & & & \\
\hline CRISIS & & $\begin{array}{c}-0.135^{\star \star \star} \\
(-12.61)\end{array}$ & & $\begin{array}{c}-0.826 * \star \star \\
(-12.11)\end{array}$ & & & & \\
\hline SIZE & & & & & $\begin{array}{c}0.182^{\star \star \star} \\
(16.00)\end{array}$ & $\begin{array}{c}0.0943^{\star \star \star} \\
(3.10)\end{array}$ & & \\
\hline M & & & & & & & $\begin{array}{c}-0.0261^{*} \\
(-1.95)\end{array}$ & $\begin{array}{c}-0.314^{\star \star \star} \\
(-34.80)\end{array}$ \\
\hline $\operatorname{ccc} x$ & & & & & & & & \\
\hline COMPETITION & $\begin{array}{c}0.01023^{* *} \\
(5.18)\end{array}$ & & $\begin{array}{c}0.108^{* * *} \\
(8.60)\end{array}$ & & & & & \\
\hline CCC X CRISIS & & $\begin{array}{c}0.0302^{\star \star \star} \\
(14.05)\end{array}$ & & $\begin{array}{c}0.179 * \star \star \\
(12.66)\end{array}$ & & & & \\
\hline
\end{tabular}


CCCX SIZE

CCC X M

INDUSTRY

YEAR

CONTROL

VARIABLES

OBSERVATIONS

HANSEN TEST $(p)$

AR1 (p)

$\operatorname{AR2}(p)$

$\begin{array}{lccc} & & & \\ \text { YES } & \text { YES } & \text { YES } & \text { YES } \\ \text { YES } & \text { YES } & \text { YES } & \text { YES } \\ & & & \\ \text { YES } & \text { YES } & \text { YES } & \text { YES } \\ 5,845 & 5,845 & 5,845 & 5,845 \\ 0.445 & 0.433 & 0.472 & 0.161 \\ 0.000 & 0.000 & 0.000 & 0.000 \\ 0.131 & 0.208 & 0.702 & 0.373\end{array}$

$0.0678^{\star \star \star}$
$(10.04)$
YES
YES
YES
5,845
0.432
0.000
0.731

$0.0332^{\star * *}$

(34.29)

YES

YES

$0.0735^{\star \star \star}$

(41.32)

YES

YES

YES YES

$5,845 \quad 5,845$

$0.194 \quad 0.412$

$0.000 \quad 0.000$

$0.182 \quad 0.884$ 
Table 10: Working Capital Management on Firms' Financial Performance

This table reports a fixed effects estimation on the relationship between working capital management and firms financial performance for across 802 UK quoted firms over the period 2004-2014, with $t$-statistics (reported in parentheses). The dependent variable is the return on assets and Tobin's

Q. All variables are defined in Table 1 . Year dummies and time dummies interacted with industry dummies were always included as regressors and as instruments. ${ }^{* * *},{ }^{* *}$ and * represent coefficients significant at the $1 \%, 5 \%$ and $10 \%$ levels correspondingly (two-tailed tests).

\begin{tabular}{|c|c|c|c|c|c|c|c|c|}
\hline & (1) & (2) & (3) & (4) & (5) & (6) & $(7)$ & (8) \\
\hline & ROA & QRATIO & ROA & QRATIO & ROA & QRATIO & ROA & QRATIO \\
\hline WCM & $\begin{array}{c}-0.068^{\star \star \star} \\
(-6.29)\end{array}$ & $\begin{array}{c}-0.053^{\star \star} \\
(-2.53)\end{array}$ & $\begin{array}{c}-0.23^{\star \star \star} \\
(-5.52)\end{array}$ & $\begin{array}{c}-0.0046 \\
(-0.47)\end{array}$ & $\begin{array}{c}-0.0003 \\
(-1.12)\end{array}$ & $\begin{array}{c}-0.0036 \\
(-0.48)\end{array}$ & $\begin{array}{c}-0.0007 \\
(-0.57)\end{array}$ & $\begin{array}{c}-0.0139 \\
(-0.77)\end{array}$ \\
\hline COMPETITION & $\begin{array}{c}2.678^{\star \star \star *} \\
(11.16)\end{array}$ & $\begin{array}{c}0.315^{\star \star} \\
(2.12)\end{array}$ & & & $\begin{array}{c}-0.103^{\star \star \star *} \\
(-3.32)\end{array}$ & & & \\
\hline CRISIS & & & $\begin{array}{c}-0.005^{\star \star} \\
(-2.28)\end{array}$ & $\begin{array}{c}-0.234^{\star \star \star} \\
(-5.52)\end{array}$ & & & & \\
\hline CEO ABILITY & & & & & & & $\begin{array}{c}-0.086^{\star * *} \\
(-3.68)\end{array}$ & $\begin{array}{c}-0.0096^{\star} \\
(-1.77)\end{array}$ \\
\hline SIZE & & & & & $\begin{array}{c}-4.975^{\star * *} \\
(-3.75)\end{array}$ & $\begin{array}{c}-0.067^{* *} \\
(-2.74)\end{array}$ & & \\
\hline $\begin{array}{l}\text { WCM X } \\
\text { COMPETITION }\end{array}$ & $\begin{array}{c}0.0190 * * * \\
(4.68)\end{array}$ & $\begin{array}{c}0.00204^{*} \\
(1.96)\end{array}$ & & & & & & \\
\hline WCM X CRISIS & & & $\begin{array}{c}0.0261^{\star *} \\
(2.34)\end{array}$ & $\begin{array}{c}0.0045^{\star *} \\
(2.28)\end{array}$ & & & & \\
\hline WCM X CEO POWER & & & & & & & $\begin{array}{c}0.189 * \star \star \\
(3.04)\end{array}$ & $\begin{array}{c}0.0207^{\star *} \\
(2.03)\end{array}$ \\
\hline WCM $\times$ SIZE & & & & & $\begin{array}{c}0.0228^{\star *} \\
(2.13)\end{array}$ & $\begin{array}{c}0.0220^{\star * *} \\
(4.08)\end{array}$ & & \\
\hline
\end{tabular}


OBSERVATIONS

CONTROL VARIABLES

FIRM-AND YEAR FIXED

EFFECTS

R-SQUARED
5,845

Yes

Yes

0.3093

$$
5,845
$$

5,845

5,845

Yes Yes

Yes

Yes Yes

0.3565

0.3103
Yes

0.3575
5,845

Yes

Yes

0.3074
5,845

Yes

Yes

0.3491
5,845

Yes

Yes

0.3094
5,845

Yes

Yes

0.3501 